\title{
Synthesis of some potent immunomodulatory and anti-inflammatory metabolites by fungal transformation of anabolic steroid oxymetholone
}

\author{
Naik Tameen Khan ${ }^{1}$, Marium Bibi', Sammer Yousuf', Izhar Husain Qureshi', Atta-ur-Rahman', \\ Abdullah Mohammad Al-Majid², Muhammad Ahmed Mesaik², Ahmed Shukralla Khalid², Samina A Sattar², \\ Atia-tul-Wahab ${ }^{2}$ and $M$ lqbal Choudhary ${ }^{1,2,3^{*}}$
}

\begin{abstract}
Background: Biotransformation of organic compounds by using microbial whole cells provides an efficient approach to obtain novel analogues which are often difficult to synthesize chemically. In this manuscript, we report for the first time the microbial transformation of a synthetic anabolic steroidal drug, oxymetholone, by fungal cell cultures.

Results: Incubation of oxymetholone (1) with Macrophomina phaseolina, Aspergillus niger, Rhizopus stolonifer, and Fusarium lini produced 17ß-hydroxy-2-(hydroxy-methyl)-17a-methyl-5a-androstan-1-en-3-one (2), 2a,17a-di(hydroxyl-

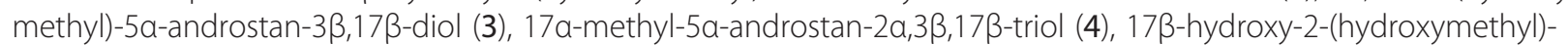
17a-methyl-androst-1,4-dien-3-one (5), 17ß-hydroxy-2a-(hydroxy-methyl)-17a-methyl-5a-androstan-3-one (6), and $2 a-(h y d r o x y m e t h y l)-17 a-m e t h y l-5 a-a n d r o s t a n-3 \beta-17 \beta-d i o l ~(7)$. Their structures were deduced by spectral analyses, as well as single-crystal X-ray diffraction studies. Compounds $2-5$ were identified as the new metabolites of 1 . The immunomodulatory, and anti-inflammatory activities and cytotoxicity of compounds $1-7$ were evaluated by observing their effects on T-cell proliferation, reactive oxygen species (ROS) production, and normal cell growth in MTT assays, respectively. These compounds showed immunosuppressant effect in the T-cell proliferation assay with $I C_{50}$ values between 31.2 to $2.7 \mu \mathrm{g} / \mathrm{mL}$, while the $I_{50}$ values for ROS inhibition, representing anti-inflammatory effect, were in the range of 25.6 to $2.0 \mu \mathrm{g} / \mathrm{mL}$. All the compounds were found to be non-toxic in a cell-based cytotoxicity assay.

Conclusion: Microbial transformation of oxymetholone (1) provides an efficient method for structural transformation of 1 . The transformed products were obtained as a result of de novo stereoselective reduction of the enone system, isomerization of double bond, insertion of double bond and hydroxylation. The transformed products, which showed significant immunosuppressant and anti-inflammatory activities, can be further studied for their potential as novel drugs.
\end{abstract}

Keywords: Oxymetholone, Anabolic steroid, Biotransformation, de novo Hydroxylation, Immunomodulation, T-Cell proliferation inhibition, Anti-inflammation, Inhibition of reactive oxygen species production, 3T3 Fibroblast cells

\footnotetext{
* Correspondence: iqbal.choudhary@iccs.edu

${ }^{1}$ H. E. J. Research Institute of Chemistry, International Center for Chemical and Biological Sciences, University of Karachi, Karachi 75270, Pakistan

${ }^{2}$ Dr. Panjwani Center for Molecular Medicine and Drug Research,

International Center for Chemical and Biological Sciences, University of

Karachi, Karachi 75270, Pakistan

Full list of author information is available at the end of the article
} 


\section{Background}

Microbial regio- and stereo-selective transformations of steroids have been extensively investigated $[1,2]$. We have been studying microbial transformation of bioactive steroids with the objectives of producing their novel metabolites and understanding their metabolism [3-8]. Oxymetholone [17 $\beta-$ hydroxy-2-(hydroxymethylene)-17 $\alpha$-methyl-5 $\alpha$-androstan-3one, $\mathrm{C}_{21} \mathrm{H}_{32} \mathrm{O}_{3}$ ] (1), a $17 \alpha$-alkylated anabolic-androgenic steroid, has been approved by the US Food and Drug Administration for the treatment of blood anemia, osteoporosis, HIV-associated wasting, antithrombin III deficiency, pediatric growth impairment, and damaged myocardium; as well as for stimulating muscle growth in malnourished, and underdeveloped individuals. However, it is also been abused by some athletes for enhancing muscle mass and strength $[9,10]$. Compound 1 also known to exhibit immunosuppressant activity in vivo by decreasing the activity of T-cells [11].

During current study, compound $\mathbf{1}$ was found to exhibit significant immunomodulatory and anti-inflammatory activities in vitro in T-cell proliferation and reactive oxygen species (ROS) production assay, respectively. T-Lymphocytes play a key role in cell mediated immune response by activating various T-cells and modulating autoimmune response. Thus inhibition of T-cell proliferation can serve as an approach to treat various immune disorders [12], including organ rejection after transplant [13]. The immune system also utilizes various cellular processes for elimination of pathogens, such as phagocytosis which involves elimination of pathogens by enzyme catalyzed oxidative burst. Ironically prolonged overproduction of ROS can damage body's own cells and tissues, and lead to chronic inflammation and other autoimmune diseases [14].

Based on these preliminary findings, we investigated biotransformation of $\mathbf{1}$ to obtain new analogues. Preliminary experiments showed that Macrophomina phaseolina, Aspergillus niger, Rhizopus stolonifer, and Fusarium lini can efficiently transform 1 into several metabolites. Subsequent large scale fermentation was carried out and four new metabolites 2-5, along with two known metabolites $\mathbf{6}$ and 7 were obtained. The structures of new metabolites were unambiguously deduced through 1D- and 2D-NMR and by single-crystal X-ray diffraction techniques. Metabolites 2-7 were then evaluated for the inhibition of T-cell proliferation ( $\mathrm{IC}_{50}$ values in the range of 31.2 to $2.7 \mu \mathrm{g} / \mathrm{mL}$ ), and ROS production ( 1 and $\mathbf{2}$ had a strong inhibition $\left(\mathrm{IC}_{50}=2\right.$ to $2.3 \mu \mathrm{g} / \mathrm{mL})$ ), representing their immunosuppressant and anti-inflammatory potential.

\section{Results and discussion}

\section{Structure elucidation of metabolites}

Incubation of oxymetholone (1) $\left(\mathrm{C}_{21} \mathrm{H}_{32} \mathrm{O}_{3}\right)$ with Macrophomina phaseolina, Aspergillus niger, Rhizopus stolonifer and Fusarium lini produced six metabolites 2-7 (Figure 1).
Metabolites 6 and 7 were previously obtained through chemical hydrogenation of $\mathbf{1}$ [15], however this is the first report of their biomimetic synthesis. The structures of new metabolites $\mathbf{2}-\mathbf{5}$ were unambiguously deduced largely by single-crystal X-ray diffraction analyses.

The HREI-MS $\left[M^{+}=m / z 332.2333\right.$ (calcd 332.2351) $\left.\left(\mathrm{C}_{21} \mathrm{H}_{32} \mathrm{O}_{3}\right)\right]$, IR $\left(1666 \mathrm{~cm}^{-1}\right)$ and UV $(236.4 \mathrm{~nm})$ spectra of 2 suggested the $\mathrm{C}=\mathrm{C}$ isomerization of $\mathbf{1}$ into 2 [8, 16]. The ${ }^{1} \mathrm{H}$ - and ${ }^{13} \mathrm{C}$-NMR spectra (Table 1 ) showed a new olefinic methine $\mathrm{H} / \mathrm{C}$ signal at $\delta 6.48 / \delta 152.4$, along with a hydroxyl-bearing methylene $\mathrm{H}_{2} / \mathrm{C}$ at $\delta 4.78$ and $4.76\left(J_{21 \mathrm{a}, \mathrm{b}}=15.0 \mathrm{~Hz}\right) / \delta 59.8$ for $\mathrm{HC}-1$ and $\mathrm{H}_{2} \mathrm{C}-21$, respectively. Me (19) protons $(\delta 0.96)$ were correlated with $C-1$ ( $\delta$ 152.4) in HMBC, while $C-21$ protons $(\delta 4.78$, 4.76) were correlated with $C-1(\delta$ 152.4) and $C-2(\delta$ 137.5). Additionally, $C-1(\delta 6.48)$ and $C-4$ protons $(\delta$ $2.47,2.26)$ were also correlated with $C-3(\delta 199.0)$, and C-2 $(\delta$ 137.5) C-1 Proton also showed HMBC correlations with $\mathrm{C}-21$ ( $\delta$ 59.8). The structure of new metabolite 2 was finally deduced through single-crystal X-ray diffraction techniques (Figure 2). The asymmetric unit contains two independent molecules of metabolite 2. The ORTEP diagrams of 2 (Figure 2) showed four trans fused rings $\mathrm{A}, \mathrm{B}, \mathrm{C}$, and D with half chair/chair/ chair, and envelop conformations, respectively. C-17 -OH and methyl groups exist in pseudo-equatorial and pseudoaxial orientations, respectively. The shorter bond lengths of C-2-C-3 single-bond (1.476(8) $\AA$ ) is due to the conjugation of C-1-C-2 (1.321(7) $\AA$ ) olefinic bond with the C-3 carbonyl moiety. All bond angles and lengths were within the normal range.

The UV inactive metabolite 3 showed molecular ion $\left(\mathrm{M}^{+}\right)$at $\mathrm{m} / \mathrm{z} 352.2643$ (calcd 352.2613), in agreement with the formula $\mathrm{C}_{21} \mathrm{H}_{36} \mathrm{O}_{4}$, indicating reduction of $\mathrm{C}=$ $\mathrm{C}$ bond and addition of any oxygen. The ${ }^{1} \mathrm{H}$ - and ${ }^{13} \mathrm{C}$ NMR spectra of 3 (Table 1) showed two pairs of downfield $\mathrm{OH}$-bearing methylene $\mathrm{H}_{2} / \mathrm{C}$ signals at $\delta 4.09,3.82$ $\left(\mathrm{d}, J_{20 \mathrm{a}, \mathrm{b}}=10.3 \mathrm{~Hz}\right) / \delta 67.3\left(\mathrm{H}_{2} \mathrm{C}-20\right)$ and $4.17,4.03(\mathrm{~m}) / \delta$ $66.1\left(\mathrm{H}_{2} \mathrm{C}-21\right)$, along with an $\mathrm{OH}$-bearing methine $\mathrm{H} / \mathrm{C}$ at $\delta 4.51$ (br. s, $\left.W_{1 / 2}=12.0 \mathrm{~Hz}\right) / \delta 67.6(\mathrm{HC}-3)$. The $\mathrm{H}_{2} \mathrm{C}-21(\delta 4.17,4.03)$ and $\mathrm{HC}-3(\delta 4.51)$ both showed COSY correlations with the vicinal HC-2 $(\delta$ 1.98). Moreover, C-21 protons showed HMBC correlations with C-1 $(\delta 36.5), C-2(\delta 40.5)$ and $C-3(\delta$ 67.6) (Figure 3a). Similarly, C-20 methylene protons at $\delta 4.09,3.82$ exhibited HMBC interactions with C-13 ( $\delta$ 46.1), C-16 ( $\delta 34.1)$, and $C-17(\delta$ 83.2). Stereochemistry at $C-2$ and $C-3$ was deduced from the NOE correlations of $\mathrm{HC}-2(\delta$ 1.98) with Me-19 ( $\delta 0.87)$, and HC-3 ( $\delta$ 4.51) with HC-5 $(\delta$ 2.01) (Figure $3 \mathrm{~b}$ ). On the basis of above observations, the new metabolite was characterized as $2 \alpha, 17 \alpha$-di (hydroxymethyl)- $5 \alpha$-androstan- $3 \beta-17 \beta$-diol (3).

The formula $\mathrm{C}_{20} \mathrm{H}_{34} \mathrm{O}_{3}$ for $4\left(M^{+}=m / z\right.$ 322.2507, calcd 322.2508) indicated four double bond equivalents 


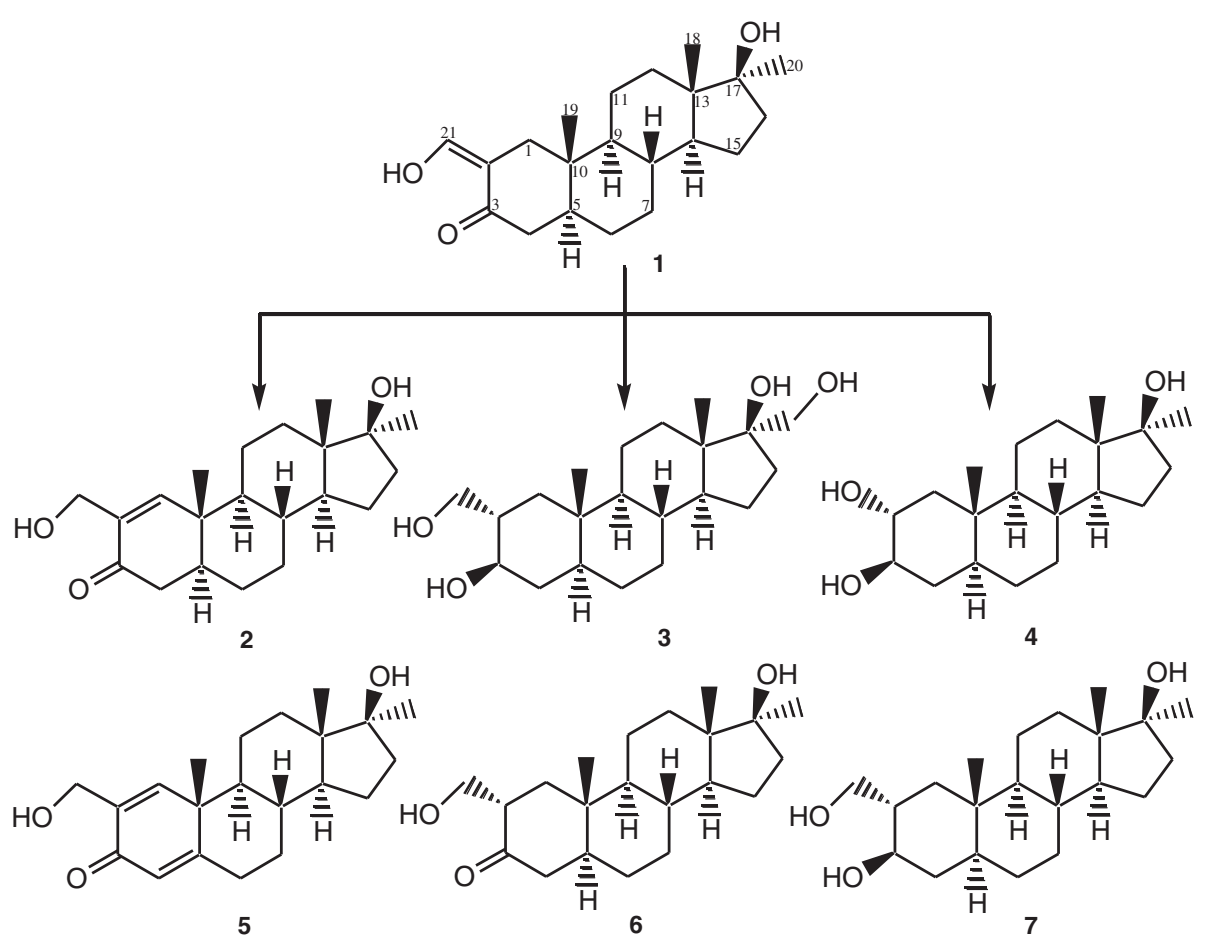

Figure 1 Biotransformation of oxymetholone (1) by Macrophomina phaseolina (compounds 2, 3, 6, 7), Aspergillus niger (compounds 6 , 7), Rhizopus stolonifer (compounds 3, 6) and Fusarium lini (compounds 2, 4, 5).

and loss of oxidative carbon. The UV and IR spectra indicated the absence of enone functionality. The ${ }^{1} \mathrm{H}$ and ${ }^{13} \mathrm{C}$-NMR (Table 1 ) of metabolite $\mathbf{4}$ was substantially different from that of the substrate $\mathbf{1}$, first due to the lack of HC-21 olefinic methine signal, and second the appearance of two new hydroxyl-bearing methine $\mathrm{H} / \mathrm{C}$ signals at $\delta 4.05\left(\mathrm{~m}, W_{1 / 2}=20.6 \mathrm{~Hz}\right) / \delta 73.1$ and $3.87(\mathrm{~m}$, $\left.W_{1 / 2}=20.6 \mathrm{~Hz}\right) / \delta$ 76.7. Vicinal correlations between $\mathrm{H}_{2} \mathrm{C}-1$ ( $\left.\delta 2.27,1.30\right), \mathrm{HC}-2$ ( $\left.\delta 4.05\right), \mathrm{HC}-3$ ( $\left.\delta 3.87\right)$ and $\mathrm{H}_{2} \mathrm{C}-4(\delta 1.88,1.72)$ in the COSY $45^{\circ}$ spectrum indicated the oxidative loss of $\mathrm{C}-21$ methine. $\mathrm{HC}-2(\delta 4.05)$ and $\mathrm{HC}-3$ ( $\delta 3.87)$ were also correlated to $\mathrm{C}-1$ ( $\delta 46.5), \mathrm{C}-4$ ( $\delta 37.2), C-5(\delta 45.4)$, and $C-10(\delta 37.6)$ in the HMBC spectrum. The structure of new metabolite 4 was unambiguously established by single-crystal X-ray diffraction analysis as half water solvate (Figure 4). It showed four trans fused rings A, B, C, and D exist in chair/ chair/ chair, and envelop conformations, respectively. The $\mathrm{C}-2$ and $\mathrm{C}-3$ vicinal diols adopt equatorial orientations, whereas hydroxyl and methyl substituents at $\mathrm{C}-17$ were found in pseudo-equatorial and pseudo-axial orientations, respectively. All bond angles and lengths were in agreement with other related steroidal structures [8].

The molecular composition $\mathrm{C}_{21} \mathrm{H}_{30} \mathrm{O}_{3}$ was deduced from the HREI-MS of metabolite $5\left(M^{+}=m / z\right.$ 330.2183, calcd 330.2195), which was 2 amu less than the metabolite 2. The UV spectrum of 5 exhibited a $\lambda_{\max }$ at $249.8 \mathrm{~nm}$ due to extended conjugation in ring $\mathrm{A}$. The ${ }^{1} \mathrm{H}$ - and ${ }^{13} \mathrm{C}$-NMR spectra (Table 1) of metabolite $\mathbf{5}$ was distinctly similar to 2 , indicating the presence of two olefinic $\mathrm{H} / \mathrm{C}$ at $\delta 7.45$ $(\mathrm{s}) / \delta 150.0(\mathrm{HC}-1)$ and $6.28(\mathrm{~d}, J=1.0 \mathrm{~Hz}) / \delta 124.0(\mathrm{HC}-4)$ in ring $\mathrm{A}$, along with hydroxy-methylene $\mathrm{H}_{2} / \mathrm{C}$ signals at $\delta$ 5.06, $4.98(\mathrm{~m}) / \delta 59.5\left(\mathrm{H}_{2} \mathrm{C}-21\right)$. The methine signals $\delta$ $6.28 / \delta 124.0$ and methylene signals $\delta 5.06,4.98 / \delta 59.5$ showed similar $\mathrm{HMBC}$ correlations as those of $\mathrm{HC}-1$ and $\mathrm{H}_{2} \mathrm{C}-21$ for metabolite 2. Similarly, C-4 proton $(\delta 6.28)$ was correlated to $C-3(\delta 186.0), C-5$ ( $\delta$ 169.4), C-6 ( $\delta 32.5)$ and $\mathrm{C}-10(\delta 43.5)$ in HMBC spectrum. The structure of metabolite 5 was unambiguously deduced by single-crystal $\mathrm{X}$-ray diffraction studies (Figure 5). The asymmetric unit contains two water solvated independent molecules of metabolite 5. The ORTEP diagrams (Figure 5) showed that compound $\mathbf{5}$ is consisting of four fused rings A, B, C and D. Trans fused rings B, C and D adopt chair/chair and envelop conformations, respectively, with the pseudo equatorial orientation of hydroxyl substituent at C-17. Ring A was found to be planner in geometry due to extended conjugation. All the bond angles and lengths were within the normal range as observed in previously reported steroids [8].

The structure of known metabolite $\mathbf{6}$ was unambiguously deduced through single-crystal X-ray diffraction studies. ORTEP diagrams (Figure 6) showed that it consists of trans fused rings A, B, C, and D with chairl chair/chair and envelop conformations, respectively. The hydroxymethylene moiety attached to $\mathrm{C}-2$, and $\mathrm{OH}$ at 
Table $1{ }^{1} \mathrm{H}$ - and ${ }^{13} \mathrm{C}$-NMR Chemical Shifts of New Compounds 2-5 ( $\delta$ in ppm; $J$ and $W_{1 / 2}$ in $\mathrm{Hz}$ )

\begin{tabular}{|c|c|c|c|c|c|c|c|c|}
\hline \multirow[t]{2}{*}{ Position } & \multicolumn{2}{|l|}{2} & \multicolumn{2}{|l|}{3} & \multicolumn{2}{|l|}{4} & \multicolumn{2}{|l|}{5} \\
\hline & $\overline{\mathrm{H}}$ & ${ }^{13} \mathrm{C}$ & ${ }^{1} \mathrm{H}$ & ${ }^{13} \mathrm{C}$ & $\overline{{ }^{1} \mathrm{H}}$ & $\frac{{ }^{13} \mathrm{C}}{}$ & $\overline{{ }^{1} \mathrm{H}}$ & ${ }^{13} \mathrm{C}$ \\
\hline 1 & $6.48, s$ & 152.4 & $1.63 ; 1.57, \mathrm{~m}$ & 36.5 & $2.28, \mathrm{dd}(12.5,4.5) ; 1.30, \mathrm{~m}$ & 46.6 & $7.45,5$ & 150.0 \\
\hline 2 & - & 137.5 & $1.98, \mathrm{~m}$ & 40.5 & $4.05, \mathrm{~m}\left(W_{1 / 2}=20.6\right)$ & 73.1 & - & 137.6 \\
\hline 3 & - & 199.0 & 4.51 , br. s $\left(W_{1 / 2} 12.0\right)$ & 67.6 & $3.86, \mathrm{~m}\left(W_{1 / 2}=20.6\right)$ & 76.7 & - & 186.0 \\
\hline 4 & 2.47, dd $(17.3,4.2), 2.26, \mathrm{dd}(17.3,4.0)$ & 41.6 & $1.71 ; 1.60 \mathrm{~m}$ & 37.7 & $1.87 \mathrm{ddd}(13.0,5.0,2.5) ; 1.72, \mathrm{~m}$ & 37.2 & $6.28, s$ & 124.0 \\
\hline 5 & $1.83, \mathrm{~m}$ & 44.8 & $2.01, \mathrm{~m}$ & 39.6 & $1.26, \mathrm{~m}$ & 45.3 & - & 169.4 \\
\hline 6 & $1.32 ; 1.27, \mathrm{~m}$ & 27.6 & $1.31 ; 1.25, \mathrm{~m}$ & 28.8 & $1.28 ; 1.22, \mathrm{~m}$ & 28.4 & $2.32,2.21, \mathrm{~m}$ & 32.5 \\
\hline 7 & $1.71 ; 0.85, \mathrm{~m}$ & 31.5 & $1.65 ; 0.90, \mathrm{~m}$ & 32.4 & $1.65 ; 0.85, \mathrm{~m}$ & 32.2 & $1.75 ; 0.85, \mathrm{~m}$ & 33.7 \\
\hline 8 & $1.44, \mathrm{~m}$ & 36.7 & $1.44, \mathrm{~m}$ & 36.4 & $1.37, \mathrm{~m}$ & 35.9 & $1.57, \mathrm{~m}$ & 36.3 \\
\hline 9 & $0.78, \mathrm{~m}$ & 50.7 & $0.76, \mathrm{~m}$ & 54.9 & $0.67, \mathrm{~m}$ & 54.7 & $0.81, \mathrm{~m}$ & 52.9 \\
\hline 10 & - & 38.9 & - & 36.6 & - & 37.6 & & 43.5 \\
\hline 11 & $1.63 ; 1.37, \mathrm{~m}$ & 21.3 & $1.57 ; 1.29, \mathrm{~m}$ & 21.0 & $1.62 ; 1.33, \mathrm{~m}$ & 21.4 & $1.65 ; 1.55, \mathrm{~m}$ & 22.9 \\
\hline 12 & $1.61 ; 1.22, \mathrm{~m}$ & 32.2 & $1.78 ; 1.49, \mathrm{~m}$ & 32.7 & $1.58,1.35, \mathrm{~m}$ & 32.0 & $1.53 ; 1.14, \mathrm{~m}$ & 31.8 \\
\hline 13 & - & 46.3 & - & 46.1 & - & 46.2 & - & 46.2 \\
\hline 14 & $1.20, \mathrm{~m}$ & 51.2 & $1.37, \mathrm{~m}$ & 51.8 & $1.24, \mathrm{~m}$ & 51.0 & $1.12, \mathrm{~m}$ & 50.2 \\
\hline 15 & $1.53 ; 1.24, \mathrm{~m}$ & 23.7 & $1.57 ; 1.34, \mathrm{~m}$ & 24.2 & $1.54 ; 1.29, \mathrm{~m}$ & 23.8 & $1.48 ; 1.30, \mathrm{~m}$ & 23.8 \\
\hline 16 & $2.14, \mathrm{ddd}(13.5,11.7,3.5) ; 1.77, \mathrm{~m}$ & 39.5 & $2.30, \mathrm{ddd}(15.6,9.2,6.7) ; 1.95, \mathrm{~m}$ & 34.1 & $2.13 ; 1.76, \mathrm{~m}$ & 39.4 & 2.14, td (13.0, 3.5); 1.78, m; & 39.2 \\
\hline 17 & - & 80.5 & - & 83.2 & - & 80.6 & - & 80.3 \\
\hline 18 & $1.08, \mathrm{~s}$ & 14.9 & $1.14, \mathrm{~s}$ & 15.2 & $1.06, \mathrm{~s}$ & 14.8 & $1.08, \mathrm{~s}$ & 14.8 \\
\hline 19 & $0.96, \mathrm{~s}$ & 13.1 & $0.87, \mathrm{~s}$ & 12.5 & $0.89, \mathrm{~s}$ & 13.7 & $1.15, \mathrm{~s}$ & 18.8 \\
\hline 20 & 1.41. s & 26.8 & $4.09 ; 3.82, d(10.3)$ & 67.3 & $1.40, \mathrm{~s}$ & 26.7 & $1.37, \mathrm{~s}$ & 26.6 \\
\hline 21 & $4.78 ; 4.76, d(15.0)$ & 59.8 & $4.17 ; 4.03, \mathrm{~m}$ & 66.1 & - & - & $5.06 ; 4.98, \mathrm{~m}$ & 59.5 \\
\hline
\end{tabular}




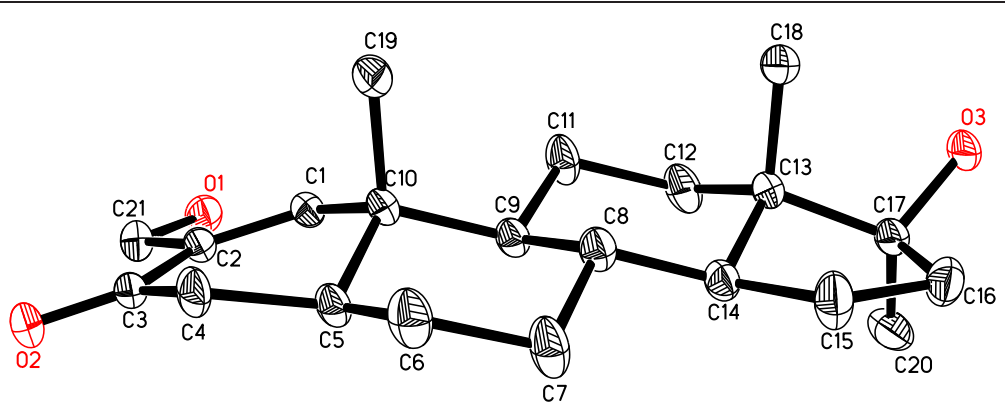

Figure 2 Computer-generated ORTEP diagram of metabolite 2 (Hydrogens are omitted for clarity).

C-17 were found in equatorial and peudo equatorial orientations, respectively. All the bond angles and lengths were found within normal range. Known metabolite 7 was structurally identified by comparing of its spectral data with the one reported earlier.

\section{T-Cell proliferation inhibitory activity}

Oxymetholone (1) is known to modulate cell-mediated immunity in vivo. This was in part due to a decrease in T-cell activity [5]. This initial observation prompted us to investigate the $\mathrm{T}$-cell proliferation inhibitory potential of $\mathbf{1}$ and its metabolites.

Compounds 1-7 were evaluated for their effect on Tcell proliferation by employing PHA to activate human peripheral mononuclear cells (PBMC), isolated from the blood sample from healthy human volunteers. The results indicate that metabolite $\mathbf{6}$ possess more potent T-cell proliferation inhibitory activity $\left(\mathrm{IC}_{50}=2.7 \mu \mathrm{g} / \mathrm{mL}\right)$, as compared to the substrate $\mathbf{1}\left(\mathrm{IC}_{50}=7.5 \mu \mathrm{g} / \mathrm{mL}\right)$ and standard prednisolone $\left(\mathrm{IC}_{50}<3.1 \mu \mathrm{g} / \mathrm{mL}\right.$ ) (Table 2, Figure 7); whereas compounds 7 and $\mathbf{4}$ showed a moderate inhibitory activity $\left(\mathrm{IC}_{50}=10.6 \pm 0.4\right.$ and $11.8 \pm 0.9 \mu \mathrm{g} / \mathrm{mL}$, respectively). Compounds 2-5 showed a weak inhibition of T-cell proliferation as compared to compounds mentioned earlier. Limited SAR indicated that greater flexibility in ring $\mathrm{A}$, due to reduction of $\mathrm{C}=\mathrm{C}$ or $\mathrm{C}=\mathrm{O}$ bonds probably contributes in activity.

\section{ROS inhibition activity}

Compounds 1-7 were also investigated for their effect on ROS production by using whole blood and professional phagocytic PMNs and the detecting probes luminal (Table 3, Figures 8 and 9). Compound 2 showed slightly stronger $(\mathrm{p} \leq 0.005)$ inhibition $\left(\mathrm{IC}_{50}=2.0 \mu \mathrm{g} / \mathrm{mL}\right)$ as compared to $\mathbf{1}$ $\left(\mathrm{IC}_{50}=2.3 \mu \mathrm{g} / \mathrm{mL}\right)$. Both compounds were at least five fold more active than the standard ibuprofen $\left(\mathrm{IC}_{50}=11.2 \mu \mathrm{g} /\right.$ $\mathrm{mL}$ ) in whole blood phagocytes. Metabolite 7 showed a moderate inhibitory activity $\left(\mathrm{IC}_{50}=25.6 \mu \mathrm{g} / \mathrm{mL}\right)$, while other compounds did not show any activity even at the highest concentration $(100 \mu \mathrm{g} / \mathrm{mL})$. Compounds which showed potent inhibitory activities were further evaluated by using professional phagocytes PMNs. Compound $\mathbf{1}$ showed a significant inhibition of ROS generation in the PMNs $\left(\mathrm{IC}_{50}=6.3 \mu \mathrm{g} / \mathrm{mL}\right)$. Interestingly ROS generation inhibitory activity of compound $\mathbf{1}$ and its known metabolites 6 and 7 have not been studied before.

\section{Cytotoxicity}

Compounds 1-7 were found to be non-toxic towards the normal mouse fibroblast (3T3) cells, even at the highest concentrations tested $(100 \mu \mathrm{g} / \mathrm{mL})$.

\section{Conclusions}

Our study provides an efficient method for the production of new anabolic steroids by the structural transformation of oxymetholone (1) by using fungi. The procedure presented

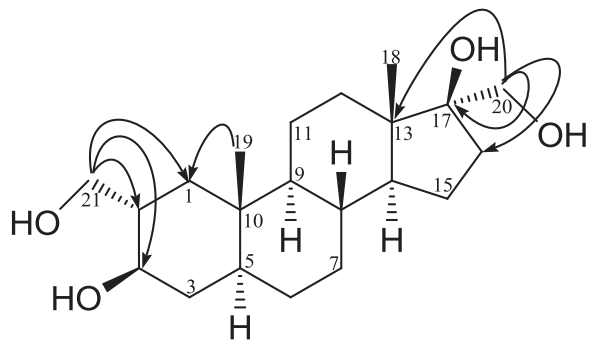

a

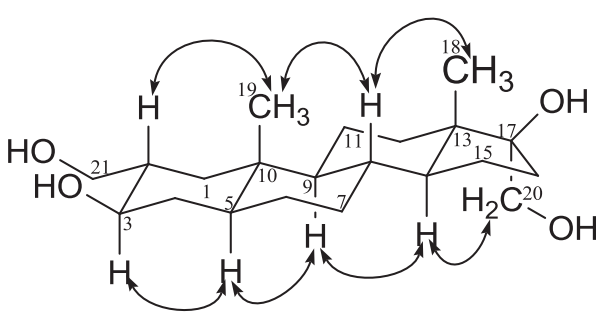

b

Figure 3 Important (a) HMBC, and (b) NOESY correlations in metabolite 3. 


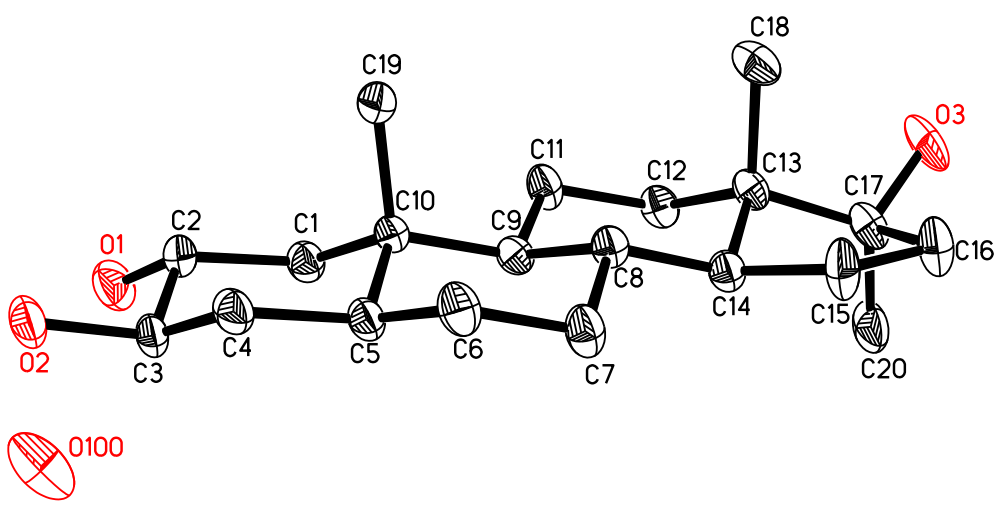

Figure 4 Computer-generated ORTEP diagram of metabolite 4 (Hydrogens are omitted for clarity).

here can also be used for the study of the metabolism of oxymetholone (1), as well as for the production of potential immunomodulatory and anti-inflammatory drugs. In the current study, compounds 2-7 found to posses a strong inhibitory effect on T-cell proliferation, with $\mathrm{IC}_{50}$ values between 31.2 to $2.7 \mu \mathrm{g} / \mathrm{mL}$, while in case of the ROS production, only compounds $\mathbf{1}$ and $\mathbf{2}$ exerted significant inhibition $\left(\mathrm{IC}_{50} \sim 2.0 \mu \mathrm{g} / \mathrm{mL}\right)$ on whole blood phagocytes. Whereas only 1 showed significant ROS inhibition $\left(\mathrm{IC}_{50}=\right.$ $6.3 \mu \mathrm{g} / \mathrm{mL}$ ) on the isolated PMNs.

\section{Experimental}

\section{General experimental conditions}

Silica gel precoated plates (Merck, $\mathrm{PF}_{254} ; 20 \times 20$, $0.25 \mathrm{~mm}$, Germany) were used for the TLC based separation. Silica gel (70-230 mesh, Merck) was used for column chromatography. Melting points were determined with a Buchi-535, apparatus and are uncorrected. Optical rotations were measured in methanol with a JASCO P2000 polarimeter. UV Spectra (in $\mathrm{nm}$ ) were recorded in methanol with a Hitachi U-3200 spectrophotometer.
Infrared (IR) spectra (in $\mathrm{cm}^{-1}$ ) were recorded with an FTIR-8900 spectrophotometer. ${ }^{1} \mathrm{H}$ - and ${ }^{13} \mathrm{C}-\mathrm{NMR}$ spectra were recorded in $\mathrm{C}_{5} \mathrm{D}_{5} \mathrm{~N}$ on a Bruker Avance NMR spectrometer, with residual solvent signal as the internal standard. Standard Bruker pulse sequences were used for 1Dand 2D-NMR experiments. The chemical shifts ( $\delta$ values) are reported in parts per million (ppm), relative to TMS at $0 \mathrm{ppm}$. The coupling constants ( $J$ values) are reported in Hertz. Electron impact (EI-MS), and high-resolution mass spectra (HREI-MS) were recorded on JEOL JMS-600H mass spectrometer (Japan); in $m / z$ (rel.\%). Single-crystal X-ray diffraction data were collected on a Bruker Smart APEX II diffractometer with CCD detector [17]. Data reductions were performed by using SAINT program. The structures were solved by direct methods [18], and refined by full-matrix least squares on F2 by using the SHELXTLPC package [19]. The figures were plotted with the aid of ORTEP program [20]. The luminometer used was from Luminoskan RS (Labsystem Luminoskan, Helsinki, Finland), and cell harvester and glass fiber filters used were from Inotech (Dottikon, Swetzerland). Liquid scintillation

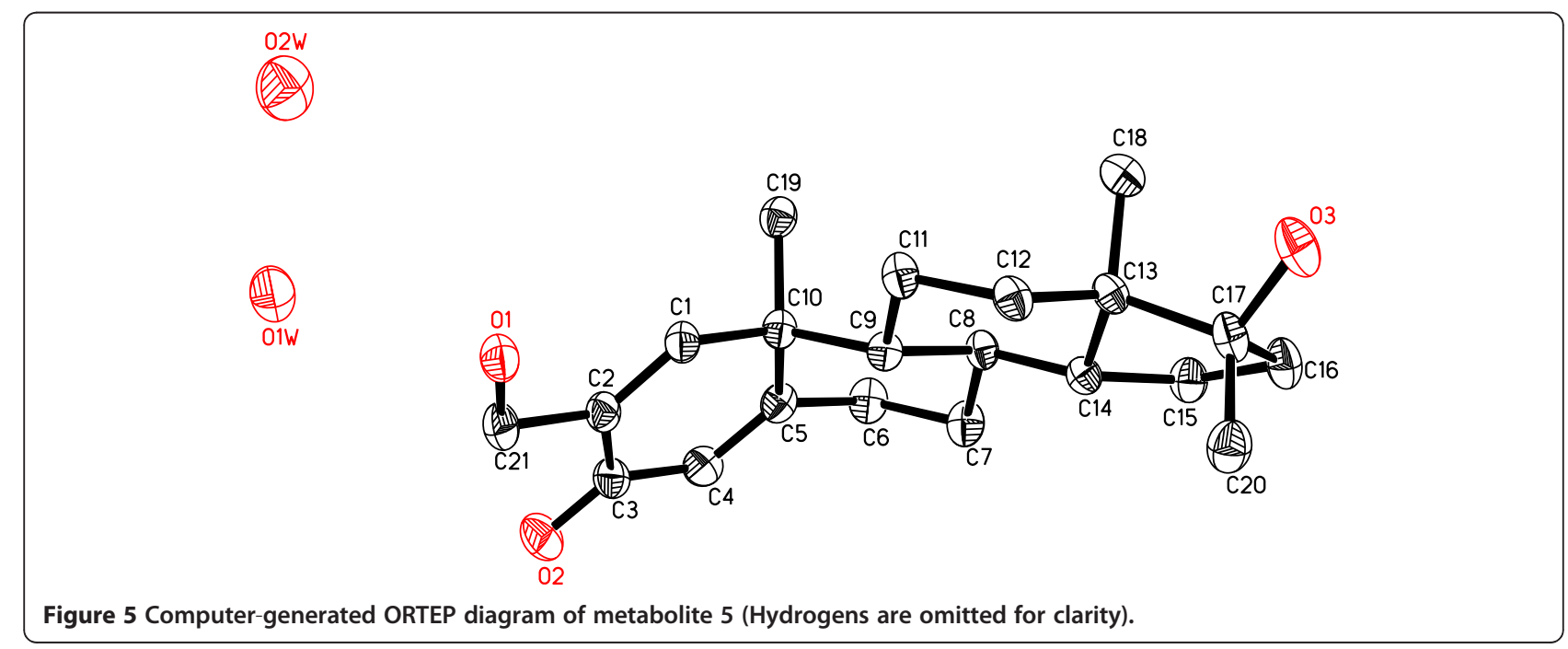




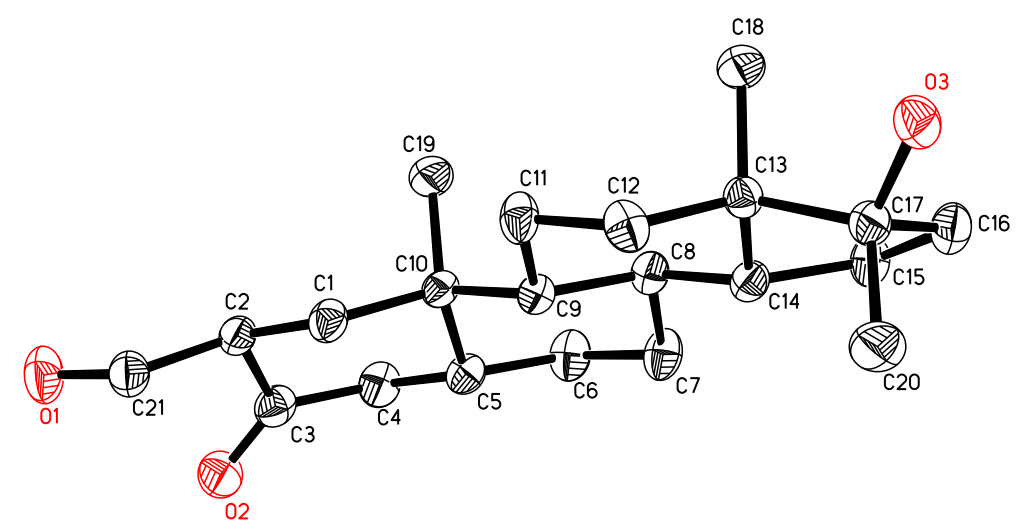

Figure 6 Computer-generated ORTEP diagram of metabolite 6 (Hydrogens are omitted for clarity).

counter used was LS65000 from Beckman Coulter (Fullerton, CA, USA). Microplate reader used was SpectraMax (Molecular Devices, CA, USA).

The chemicals and reagents were purchased from the following sources: Oxymetholone (1) (TCI, Japan), Luminol (Research Organics, OH, USA), Hanks balance salts solution (HBSS), phytohemagglutinin-L (PHA-L), penicillin, and streptomycin (Sigma,St. Louis, USA), lymphocytes separation medium (LSM) (MP Biomedicals, Illkirch, France), zymosan-A (Saccharomyces cerevisiae) (Fluka BioChemika, Buchs, Switzerland), tritiated thymidine (Amersham Pharmacia Biotech, UK) and 3-[4,5dimethylthiazol-2-yl]-2,5-diphenyl-tetrazolium bromide (MTT) (Amresco, Solon, OH, USA).

Tissue culture plates were obtained from Iwaki (Japan). Mouse fibroblasts (3T3) were obtained from the European American Culture Collection (EACC). Dulbcco's modified eagle medium (DMEM) and fetal bovine serum were purchased from Gibco-BRL (Grand Island, NY, USA).

\section{Microorganisms and culture medium}

The fungi were obtained either from the Northern Regional Research Laboratories (NRRL), or Karachi University Culture

Table 2 Inhibitory effect of compounds on the T-cell proliferation in comparison to standard

\begin{tabular}{|c|c|}
\hline Compound & $\left.I C_{50} \mu \mathrm{g} / \mathrm{mL}^{\mathrm{a}}\right)$ \\
\hline 1 & $7.5 \pm 0.4$ \\
\hline 2 & $17.4 \pm 1.2$ \\
\hline 3 & $17.0 \pm 1.2$ \\
\hline 4 & $11.8 \pm 0.9$ \\
\hline 5 & $31.2 \pm 1.9$ \\
\hline 6 & $2.7 \pm 0.2$ \\
\hline 7 & $10.6 \pm 0.4$ \\
\hline Standard (Prednisolone) & $<3.1$ \\
\hline
\end{tabular}

$\left.{ }^{\mathrm{a}}\right)$ Each $\mathrm{IC}_{50}$ value represents the mean value of triplicate reading $\pm \mathrm{SD}$.
Collection (KUCC) or American Type Culture Collection (ATCC).

Macrophomina phaseolina (KUCC 730) and Fusarium lini (NRRL 2204) were grown in a medium composed of the following ingredients and dissolved in distilled $\mathrm{H}_{2} \mathrm{O}$ $(4.0 \mathrm{~L})$ : glucose $(40.0 \mathrm{~g})$, glycerol $(40.0 \mathrm{~mL})$, peptone $(20.0 \mathrm{~g})$, yeast extract $(20.0 \mathrm{~g}), \mathrm{KH}_{2} \mathrm{PO}_{4}(20.0 \mathrm{~g})$, and $\mathrm{NaCl}$ $(20.0 \mathrm{~g})$. The media $(2.0 \mathrm{~L})$ for Aspergillus niger (ATCC 10549), and Rhizopus stolonifer (ATCC 10404) were the same as above, except addition of glycerol $(10.0 \mathrm{~mL})$ for $A$. niger and yeast extract $(6.0 \mathrm{~g})$ for $R$. stolonifer.

\section{General fermentation and extraction conditions}

The fungal medium was distributed into $250 \mathrm{~mL}$ conical flasks $\left(100 \mathrm{~mL}\right.$ each) and autoclaved at $121^{\circ} \mathrm{C}$. Mycelia of the fungi were transferred to flasks and incubated at $26 \pm 2^{\circ} \mathrm{C}$ for two-three days on rotary shaking (120 rpm). Compound 1, dissolved in acetone, was evenly distributed among all the flasks which were placed on the rotary shaker $(120 \mathrm{rpm})$ at $26 \pm 2^{\circ} \mathrm{C}$ for fermentation. Parallel control experiments were conducted which included an incubation of the fungus without substrate $\mathbf{1}$, and an incubation of $\mathbf{1}$ in the medium without fungus. The degree of transformation was analyzed on TLC after one day. The culture medium and mycelium were separated by filtration. The mycelium was washed with dichloromethane $\left(\mathrm{CH}_{2} \mathrm{Cl}_{2}, 1.0 \mathrm{~L}\right)$. The aqueous filtrate was extracted with $\mathrm{CH}_{2} \mathrm{Cl}_{2}(4 \mathrm{~L} \times 3)$. The $\mathrm{CH}_{2} \mathrm{Cl}_{2}$ extract was dried over anhydrous $\mathrm{Na}_{2} \mathrm{SO}_{4}$, evaporated under reduced pressures, and the resulting brown gum was analyzed by thin-layer chromatography. The control flasks were also harvested in the same manner, and compared with the test to assure the presence of biotransformed products.

\section{Fermentation of oxymetholone (1) with Macrophomina phaseolina}

Oxymetholone $(\mathbf{1} ; 800 \mathrm{mg})$ was dissolved in $20 \mathrm{~mL}$ acetone, and uniformly distributed to 40 flasks containing 


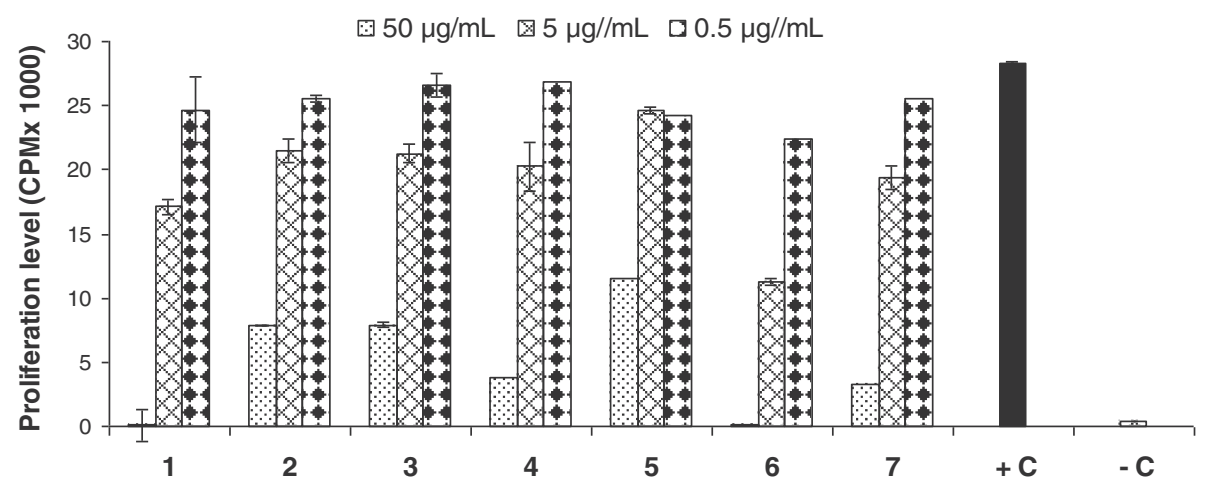

Figure 7 Effect of compounds 1-7 on phytohemagglutinin (PHA) activated T-cell proliferation. The effect of compounds on the T-cell proliferation is compared with control. Each bar represents the mean value of triplicate reading \pm SD

2 days old M. phaseolina culture. Fermentation was carried out for twelve days. The gummy material $(2.5 \mathrm{~g})$, obtained after filtration, extraction and evaporation, was loaded onto a silica gel column for fractionation. The mobile phase was composed of pet. ether and acetone with a gradient of $10 \%$. Three main fractions (OX-1-3) were obtained on the basis of TLC analysis. Fraction OX-1 yielded metabolites $2(07 \mathrm{mg})$ and $6(43 \mathrm{mg})$ on elution from silica gel column (pet. ether: acetone $=9: 1$ ), while OX-2, when subjected to silica gel column chromatography, yielded metabolite $7(21 \mathrm{mg}$, pet. ether: acetone $=8: 2$ ). Fraction OX-3 yielded metabolite 3 $(276 \mathrm{mg}$, pet. ether: acetone $=7: 3)$ after elution from silica gel column.

\section{7ß-Hydroxy-2-(hydroxymethyl)-17a-methyl-5a-androstan- 1-en-3-one (2)}

Colorless crystalline solid; m.p. $173-174^{\circ} \mathrm{C} ;[\alpha]_{\mathrm{D}}^{25}-45.4(c$ 0.03, MeOH); UV (MeOH): $\lambda_{\max } \mathrm{nm}(\log \varepsilon) 236.4$ (3.9); IR (KBr): $v_{\max }: 3358,1666,1629,1095 \mathrm{~cm}^{-1}$; ${ }^{1} \mathrm{H}-\mathrm{NMR}$ : $\left(500 \mathrm{MHz}, \mathrm{C}_{5} \mathrm{D}_{5} \mathrm{~N}\right)$ see Table 2; ${ }^{13} \mathrm{C}-\mathrm{NMR}$ : $(125 \mathrm{MHz}$, $\left.\mathrm{C}_{5} \mathrm{D}_{5} \mathrm{~N}\right)$ see Table 2; EI-MS (\%): $\mathrm{m} / z 332\left(M^{+}, 30\right), 274$ (25), 216 (20), 176 (39), 174 (52), 161 (34), 147 (24), 123 (32), 108 (31), 91 (56), 71 (100), 55 (95); HREI-MS: $m / z$
332.2333 $\left(\mathrm{M}^{+}\left[\mathrm{C}_{21} \mathrm{H}_{32} \mathrm{O}_{3}\right]^{+}\right.$, calcd 332.2351). Crystal data: empirical formula $=\mathrm{C}_{21} \mathrm{H}_{32} \mathrm{O}_{3}, M r=332.47$, orthorhombic, space group $\mathrm{P} 22_{1} 22_{1}, a=7.715$ (4) $\AA, b=$ 13.604 (7) $\AA, c=36.769$ (16) $\AA, V=3859$ (3) $\AA^{3}, Z=8$, $\rho_{\text {calc }}=1.145 \mathrm{mg} \mathrm{m}^{-3}, \quad \mathrm{~F}(000)=1456, \mu \quad($ Mo $\mathrm{K} \alpha)=$ $0.71073 \AA$, max $/$ min transmission $0.9948 / 0.9867$, crystal dimensions $0.18 \times 0.13 \times 0.07 \mathrm{~mm}, \quad 1.11^{\circ}<\theta<25.50^{\circ}$, 22,826 reflections were collected, out of which 4,091 reflections were observed $\left(R_{\mathrm{int}}=0.1228\right)$ and 433 parameters were refined. The $R$-values were; $R_{1}=0.0610$, $w R_{2}=0.1293$ for $\mathrm{I}>2 \sigma(\mathrm{I})$, and $R_{1}=0.1210, w R_{2}=0.1691$ for all data, $\mathrm{max} / \mathrm{min}$ residual electron density; 0.226/0.229 e $\AA^{-3}$. Crystallographic data for compound 2 can be obtained from the Cambridge Crystallographic Data Center, through the allocated deposition code CCDC 795529 (Additional file 1 and Additional file 2).

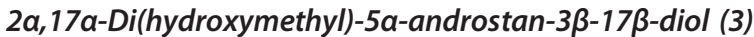

Amorphous material; $[\alpha]_{\mathrm{D}}^{25}-14.3(c=0.03, \mathrm{MeOH})$; IR $(\mathrm{KBr}): v_{\max }$ 3382, $1381 \mathrm{~cm}^{-1}$. ${ }^{1} \mathrm{H}-\mathrm{NMR}:(600 \mathrm{MHz}$, $\left.\mathrm{C}_{5} \mathrm{D}_{5} \mathrm{~N}\right)$ see Table $3 ;{ }^{13} \mathrm{C}-\mathrm{NMR}:\left(150 \mathrm{MHz}, \mathrm{C}_{5} \mathrm{D}_{5} \mathrm{~N}\right)$ see Table 3; EI-MS (\%): $m / z 352\left(M^{+}, 6\right), 334$ (26), 316 (14), 303 (72), 285 (100), 260 (55), 245 (49), 229 (23), 177 (23), 161 (33), 147 (37), 107 (47), 93 (42), 55 (26); HREI-

Table 3 Inhibitory effects of compounds on ROS production in human whole blood and PMNs

\begin{tabular}{|c|c|c|}
\hline Compound & $\left.\mathrm{IC}_{50} \mu \mathrm{g} / \mathrm{mL}^{\mathrm{a}}\right)$ (Whole Blood phagocytes) & $\left.\mathrm{IC}_{50} \mu \mathrm{g} / \mathrm{mL}^{\mathrm{a}}\right)(\mathrm{PMNs})$ \\
\hline 1 & $2.3 \pm 0.0$ & $6.3 \pm 0.1$ \\
\hline 2 & $2.0 \pm 0.8$ & - \\
\hline 3 & $>100$ & $>50$ \\
\hline 4 & $>100$ & $>50$ \\
\hline 5 & $>100$ & $>50$ \\
\hline 6 & $>100$ & $>50$ \\
\hline 7 & 25.6 & $>50$ \\
\hline Standard (Ibuprofen) & $11.2 \pm 1.9$ & $2.5 \pm 0.6$ \\
\hline
\end{tabular}

$\left.{ }^{\mathrm{a}}\right)$ Each $\mathrm{IC}_{50}$ value represents the mean value of triplicate reading \pm SD. 


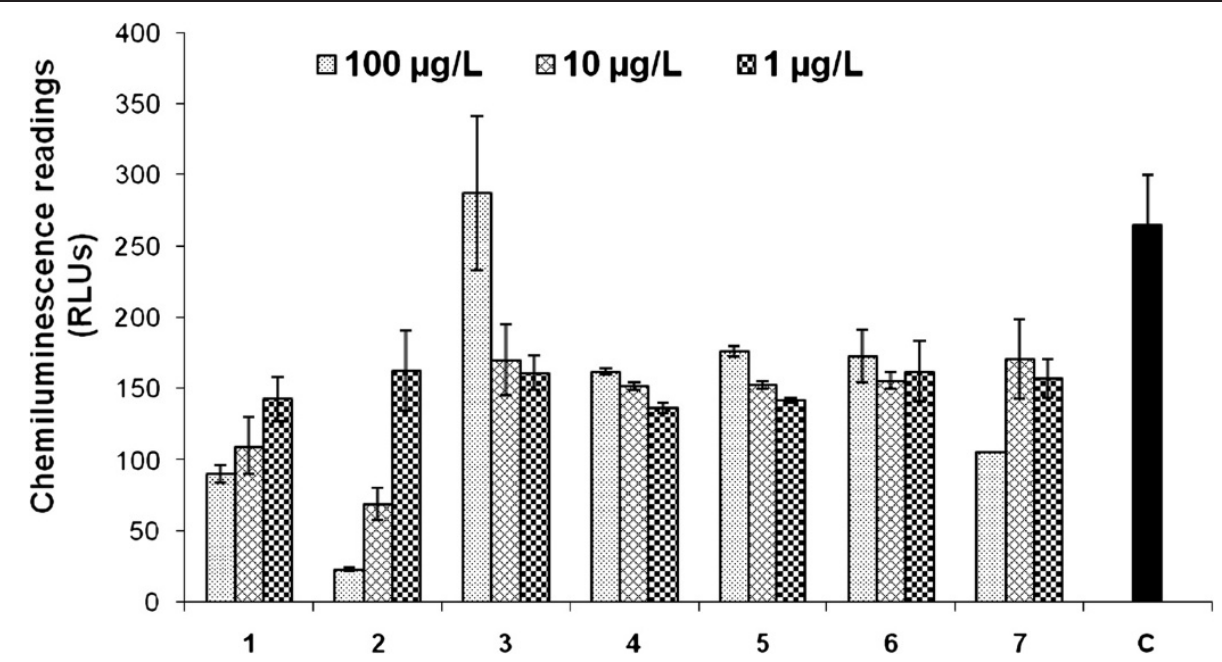

Figure 8 Effect of compounds 1-7 on reactive oxygen species (ROS) production using whole blood phagocytes. The compounds activity was compared with the control $(C=$ cells with activator). Each plot and error bar represents reading \pm SD of three repeats

MS: $m / z 352.2623\left(\mathrm{M}^{+}\left[\mathrm{C}_{21} \mathrm{H}_{36} \mathrm{O}_{4}\right]^{+}\right.$, calcd 352.2613) (Additional file 3).

\section{$17 \beta-H y d r o x y-2 a-(h y d r o x y m e t h y l)-17 a-m e t h y l-5 a-a n d r o s t a n-$}

\section{3-one (6)}

Colorless crystalline solid; m.p. $197-199^{\circ} \mathrm{C}$. [lit. $\left.198-200^{\circ} \mathrm{C}\right]$ $[15] ;[\alpha]_{\mathrm{D}}^{25}+13.5(c 0.04, \mathrm{MeOH})[$ [it. +19.7$]$. Crystal data: empirical formula $=\mathrm{C}_{21} \mathrm{H}_{34} \mathrm{O}_{3}, M r=334.48$, orthorhombic, space group $\mathrm{P} 2{ }_{1} 2_{1} 2_{1}, a=7.3859$ (3) $\AA, b=20.6898$ (9) $\AA$, $c=12.4157$ (6) $\AA, V=1897.27 \quad(15) \AA^{3}, Z=4, \quad \rho_{\text {calc }}=$ $1.171 \mathrm{mg} \mathrm{m}^{-3}, \mathrm{~F}(000)=736, \mu($ Mo $\mathrm{K} \alpha)=0.71073 \AA$, max $/$ min transmission $0.9962 / 0.9754$, crystal dimensions $0.33 \mathrm{x}$ $0.21 \times 0.05 \mathrm{~mm}, 1.64^{\circ}<\theta<27.50^{\circ}, 18840$ reflections were collected, out of which 4479 reflections were observed $\left(R_{\text {int }}=0.0422\right)$ and 437 parameters were refined. The $R$-values were; $R_{1}=0.0534, w R_{2}=0.1354$ for $\mathrm{I}>2 \sigma(\mathrm{I})$, and $R_{1}=0.0707, w R_{2}=0.1472$ for all data, $\max / \mathrm{min}$ residual electron density; $0.433 /-0.214 \mathrm{e} \AA^{-3}$. Crystallographic data for compound $\mathbf{6}$ can be obtained from the Cambridge Crystallographic Data Center (code CCDC 795530) (Additional file 4 and Additional file 5).

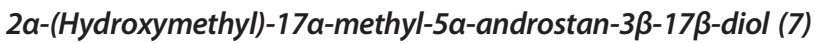
Colorless crystalline solid; m.p. $279-281^{\circ} \mathrm{C}$. [lit. $280-282^{\circ} \mathrm{C}$ ]

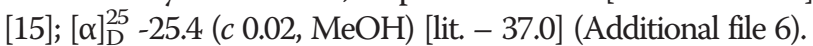

Fermentation of oxymetholone (1) with Aspergillus niger and Rhizopus stolonifer

Incubation of 1 ( $400 \mathrm{mg} / 10 \mathrm{~mL}$ acetone) with 2 days old culture of $A$. niger in 20 flasks for 6 days produced the previously isolated metabolites $6(64 \mathrm{mg})$ and $7(136 \mathrm{mg})$, while $R$. stolonifer (20 flasks) transformed $1(400 \mathrm{mg} /$ $10 \mathrm{~mL}$ acetone) into metabolites $3(86 \mathrm{mg})$ and $\mathbf{6}(15 \mathrm{mg})$.

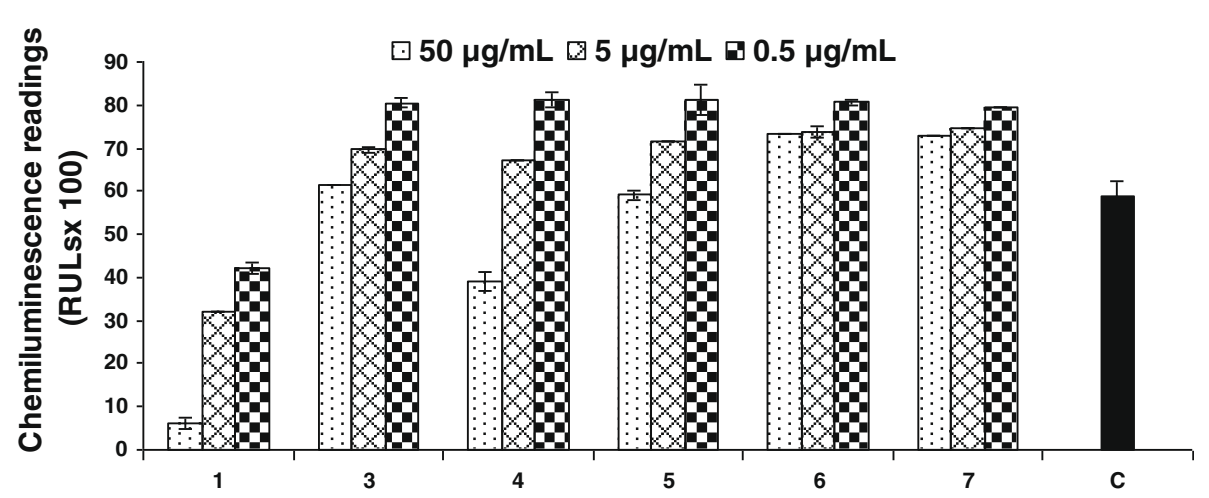

Figure 9 Effect of compounds 1 and 3-7 on reactive oxygen species (ROS) production using isolated neutrophils. The compounds activity was compared with the control ( $C=$ cells with activator). Each plot and error bar represents reading \pm SD of three repeats 


\section{Fermentation of oxymetholone (1) with Fusarium lini}

Incubation of 1 (600 mg/15 mL acetone) with 2-day old $F$. lini culture in 30 flasks for 12 days produced three metabolites which were purified by silica gel column chromatography to obtain metabolites 2 (146 mg), 4 (32 mg, pet. ether: acetone $=7: 3)$ and $5(15 \mathrm{mg}$, pet. ether: acetone $=7: 3)$.

\section{7a-Methyl-5a-androstan-2a,3 $\beta-17 \beta$-triol (4)}

Colorless crystalline solid; m.p.: $124-125^{\circ} \mathrm{C} .[\alpha]_{\mathrm{D}}^{25}:-29.0$ $(c=0.01, \mathrm{MeOH})$. IR (KBr): $v_{\max } 3409,2927,1051 \mathrm{~cm}^{-1}$; ${ }^{1} \mathrm{H}-\mathrm{NMR}:\left(500 \mathrm{MHz}, \mathrm{C}_{5} \mathrm{D}_{5} \mathrm{~N}\right)$ see Table $3 ;{ }^{13} \mathrm{C}-\mathrm{NMR}$ : (125 MHz, $\left.\mathrm{C}_{5} \mathrm{D}_{5} \mathrm{~N}\right)$ see Table 3; EI-MS (\%): $m / z 322\left(M^{+}\right.$, 98), 307 (100), 304 (43), 264 (39), 249 (95), 229 (30), 215 (53), 181 (54), 171 (58), 169 (51), 123 (55), 109 (33), 95 (41), 81 (40), 57 (30), 43 (42); HREI-MS: $m / z 322.2507\left(\mathrm{M}^{+}\right.$ $\left[\mathrm{C}_{20} \mathrm{H}_{34} \mathrm{O}_{3}\right]^{+}$, calcd 322.2508); Crystal data: empirical formula $=\mathrm{C}_{20} \mathrm{H}_{35} \mathrm{O}_{4} \quad\left[\mathrm{C}_{20} \mathrm{H}_{34} \mathrm{O}_{3} \cdot \mathrm{OH}\right], \quad M r=339.48$, monoclinic, space group $\mathrm{P} 21, a=11.5169$ (19) $\AA, b=6.7843$ (12) $\AA, \quad c=12.820$ (2) $\AA, V=945.6 \quad(3) \AA^{3}, Z=2, \rho_{\text {calc }}=$ $1.192 \mathrm{mg} \mathrm{m}^{-3}, \mathrm{~F}(000)=374, \mu($ Mo $\mathrm{K} \alpha)=0.71073 \AA$, $\max /$ min transmission $0.9912 / 0.9785$, crystal dimensions $0.27 \times$ $0.12 \times 0.11 \mathrm{~mm}, 1.68^{\circ}<\theta<25.50^{\circ}, 4,363$ reflections were collected, out of which 1,585 reflections were observed $\left(R_{\text {int }}=0.0493\right)$ and 221 parameters were refined. The $R$ values were; $R_{1}=0.0452, W R_{2}=0.0808$ for $\mathrm{I}>2 \sigma$ (I), and $R_{1}=0.0791, W R_{2}=0.0914$ for all data, $\max / \mathrm{min}$ residual electron density; 0.147/-0.141 e $\AA^{-3}$. Crystallographic data for compound $\mathbf{4}$ can be obtained from the Cambridge Crystallographic Data Center (code CCDC 795528) (Additional file 7 and Additional file 8).

\section{7ß-Hydroxy-2-(hydroxymethyl)-17a-methylandrost-1,4- dien-3-one (5)}

Colorless crystalline solid; m.p. $163-164^{\circ} \mathrm{C} ;[\alpha]_{\mathrm{D}}^{25}-33.0(c=$ 0.01, MeOH); UV (MeOH): $\lambda_{\max } n m(\log \varepsilon): 249.8$ (4.0). IR $(\mathrm{KBr}): v_{\max } 3402,1664,1620,1082,1033 \mathrm{~cm}^{-1} .{ }^{1} \mathrm{H}-\mathrm{NMR}$ : (500 MHz, $\left.\mathrm{C}_{5} \mathrm{D}_{5} \mathrm{~N}\right)$ see Table $3 .{ }^{13} \mathrm{C}-\mathrm{NMR}:(125 \mathrm{MHz}$, $\left.\mathrm{C}_{5} \mathrm{D}_{5} \mathrm{~N}\right)$ see Table 3. EI-MS (\%): $m / z 330\left(M^{+}, 35\right), 312$ (19), 294 (13), 254 (17), 161 (24), 152 (76), 147 (29), 134 (100), 121 (34), 107 (18), 91 (14). HREI-MS: $m / z$ 330.2183 $\left(M^{+},\left[\mathrm{C}_{21} \mathrm{H}_{30} \mathrm{O}_{3}\right]^{+}\right.$; calcd 330.2195). Crystal data: empirical formula $=\mathrm{C}_{42} \mathrm{H}_{62} \mathrm{O}_{8}, M r=694.92$, monoclinic, space group

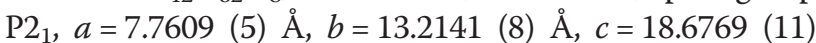
$\AA, V=1913.9(2) \AA^{3}, \mathrm{Z}=2, \rho_{\text {calc }}=1.206 \mathrm{mg} \mathrm{m}^{-3}, \mathrm{~F}(000)=$ 756, $\mu($ Mo $\mathrm{K} \alpha)=0.71073 \AA$ A, $\max / \mathrm{min}$ transmission $0.9879 / 0.9751$, crystal dimensions $0.31 \times 0.17 \times 0.15 \mathrm{~mm}$, $1.09^{\circ}<\theta<25.00^{\circ}, 10,983$ reflections were collected, out of which 3,534 reflections were observed $\left(R_{\text {int }}=0.0364\right)$ and 458 parameters were refined. The $R$-values were; $R_{1}=0.0523, w R_{2}=0.1342$ for $\mathrm{I}>2 \sigma(\mathrm{I})$, and $R_{1}=0.0699$, $w R_{2}=0.1544$ for all data, $\max / \mathrm{min}$ residual electron density; 0.320/-0.311 e $\AA^{-3}$. Crystallographic data for compound 5 can be obtained from the Cambridge Crystallographic
Data Center (code CCDC 799213) (Additional file 9 and Additional file 10).

\section{T-Cell proliferation inhibition assay}

Peripheral blood mononuclear cells (PBMC) were isolated from heparinized venous blood of healthy adult donors by Ficoll-Hypaque gradient centrifugation [21]. Cells were proliferated as reported earlier [22]. Briefly, cells were cultured at a concentration of $2 \times 10^{6} / \mathrm{mL}$ in a 96-well round bottom tissue culture plate. Cells were stimulated with $5 \mu \mathrm{g} / \mathrm{mL}$ of phytohemagglutinin. Various concentrations of compounds were added to obtain final concentrations of $0.5,5,50 \mu \mathrm{g} / \mathrm{mL}$, each in triplicate. The plate was incubated for $72 \mathrm{~h}$ at $37^{\circ} \mathrm{C}$ in $5 \% \mathrm{CO}_{2}$ environment. After $72 \mathrm{~h}$, cells were pulsed with $0.5 \mu \mathrm{Ci} /$ well, tritiated thymidine, and further incubated for $18 \mathrm{~h}$. Cells were harvested onto a glass fiber filter by using cell harvester. The tritiated thymidine incorporation into the cells, which reflects the proliferation level, was measured by a liquid scintillation counter.

\section{Phagocyte chemiluminescence assay}

Luminol-enhanced chemiluminescence assay was performed according to the previous reported method [23]. Briefly $25 \mu \mathrm{L}$ of whole blood or neutrophils $\left(1 \times 10^{6} / \mathrm{mL}\right)$, suspended in Hank's solution, were incubated with $25 \mu \mathrm{L}$ compounds $(1,10,100 \mu \mathrm{g} / \mathrm{mL}$ for whole blood and $0.5,5$, $50 \mu \mathrm{g} / \mathrm{mL}$ for neutrophils) for $30 \mathrm{~min}$. Zymosan $25 \mu \mathrm{L}$ $(20 \mathrm{mg} / \mathrm{mL})$, followed by $25 \mu \mathrm{L}\left(7 \times 10^{-5} \mathrm{M}\right)$ of luminol was added to make a final volume of $100 \mu \mathrm{L}$. A control without the compound was also run. Peak chemiluminescence was recorded using the luminometer. The luminometer was set with repeated scan mode, 50 scans with $30 \mathrm{~s}$ intervals and one second point measuring time.

\section{Cytotoxicity assay}

The cytotoxicity of compounds was determined by using the MTT cellular assay [24, 25] against a normal mouse fibroblast (3T3) cell line. Cells were grown in DMEM and MEM (modified Eagle's medium), containing 10\% FBS and $2 \%$ antibiotic (penicillin and streptomycin), and maintained at $37^{\circ} \mathrm{C}$ in $5 \% \mathrm{CO}_{2}$ for 24 hours in a flask. Cells were plated $\left(1 \times 10^{5}\right.$ cell $\left./ \mathrm{mL}\right)$ in 96 -well flat bottom plates and incubated for 24 hours for cell attachment. Various concentrations of compounds, ranging between 1.25$100 \mu \mathrm{M}$, were added into the well and incubated for 48 hours. A $50 \mu \mathrm{L}$ [2 mg/mL] MTT, 3-(4,5-dimethylthiazol-2-yl)-2,5-diphenyltetrazolium bromide was added to the well, 4 hours before the end of incubation. Medium and reagents were aspirated and $100 \mu \mathrm{L}$ DMSO was added and mixed thoroughly for 15 minutes to dissolve the formazan crystals. The absorbance was measured at $570 \mathrm{~nm}$ by using a microplate reader. Finally, $\mathrm{IC}_{50}(\mu \mathrm{M})$ values were calculated, and the experiment was repeated at least 
three times. Cycloheximide was used as the standard for normal fibroblast cell line.

\section{Additional files} Additional file 1: Spectroscopic data of compound 2. Include spectra
of ${ }^{1} \mathrm{H}-\mathrm{NMR}, \mathrm{El}-\mathrm{MS}, \mathrm{HREI}-\mathrm{MS}, \mathrm{IR}$, and UV experiments.

Additional file 2: Crystallographic information file (cif) of compound 2.

Additional file 3: Spectroscopic data of compound 3. Include spectra of ${ }^{1} \mathrm{H}-\mathrm{NMR},{ }^{13} \mathrm{C}-\mathrm{NMR}$ (BB, DEPT-135), HSQC, HMBC, COSY-45 , NOESY, ElMS, HREI-MS, and IR experiments.

Additional file 4: Spectroscopic data of compound 6. Include spectra of ${ }^{1} \mathrm{H}-\mathrm{NMR},{ }^{13} \mathrm{C}-\mathrm{NMR}$ (BB, DEPT-135), HMQC, HMBC, COSY-45, NOESY, and El-MS.

Additional file 5: Crystallographic information file (cif) of compound 6.

Additional file 6: Spectroscopic data of compound 7. Include spectra of ${ }^{1} \mathrm{H}-\mathrm{NMR},{ }^{13} \mathrm{C}-\mathrm{NMR}$ (BB, DEPT-135), HMQC, HMBC, COSY-45', NOESY, and El-MS.

Additional file 7: Spectroscopic data of compound 4. Include spectra of ${ }^{1} \mathrm{H}-\mathrm{NMR},{ }^{13} \mathrm{C}-\mathrm{NMR}$ (BB, DEPT-135), HSQC, HMBC, COSY-45, NOESY, El-MS, HREI-MS, IR and UV experiments.

Additional file 8: Crystallographic information file (cif) of compound 4.

Additional file 9: Spectroscopic data of compound 5. Include spectra of ${ }^{1} \mathrm{H}-\mathrm{NMR},{ }^{13} \mathrm{C}-\mathrm{NMR}$ (BB, DEPT-135), HSQC, HMBC, COSY-45 ${ }^{\circ}$, NOESY, EI-MS, HREI-MS, and IR experiments.

Additional file 10: Crystallographic information file (cif) of compound 5.

\section{Competing interests}

The authors have no competing interests.

\section{Authors' contributions}

MIC, AR, MAM and AMA-M participated in experimental strategy design, supervision and manuscript writing. NTK, MB and IHQ carried out the experiments. SY carried out the X-ray diffraction experiments. AW performed NMR experiments while MAM, ASK and SAS carried out the biological screenings. All authors read and approved the final manuscript.

\section{Acknowledgements}

One of us (Naik T. Khan) acknowledges the enabling role of the Higher Education Commission, Islamabad, Pakistan, by a financial support through "Indigenous Fellowship Program (5000 Scholarships)".

\section{Author details}

${ }^{1} H$. E. J. Research Institute of Chemistry, International Center for Chemical and Biological Sciences, University of Karachi, Karachi 75270, Pakistan. ${ }^{2}$ Dr Panjwani Center for Molecular Medicine and Drug Research, International Center for Chemical and Biological Sciences, University of Karachi, Karachi 75270, Pakistan. ${ }^{3}$ Department of Chemistry, College of Sciences, King Saud University, Riyadh 11451, Saudi Arabia.

Received: 27 September 2012 Accepted: 20 November 2012 Published: 10 December 2012

\section{References}

1. Fernandes P, Cruz A, Angelova B, Pinheiro HM, Cabral JMS: Microbial conversion of steroid compounds: recent developments. Enzyme Microb Technol 2003, 32:688-705.

2. Charney W, Herzog HL: Microbial Transformations of Steroids. New York: Academic Press: 1967:16-73.

3. Choudhary MI, Erum S, Atif M, Malik R, Khan NT, Atta-ur-Rahman: Biotransformation of (20S)-20-hydroxymethylpregna-1,4-dien-3-one by four filamentous fungi. Steroids 2011, 76:1288-1296.

4. Choudhary MI, Shah SA, Atta-ur-Rahman, Khan SN, Khan MTH: Alphaglucosidase and tyrosinase inhibitors from fungal hydroxylation of tibolone and hydroxytibolones. Steroids 2010, 75:956-966.

5. Al-Aboudi A, Mohammad MY, Haddad S, Al-Far R, Choudhary MI, Atta-urRahman: Biotransformation of methyl cholate by Aspergillus niger. Steroids 2009, 74:483-486
6. Azizuddin, Choudhary Ml: Biotransformation of danazol by Fusarium solani and Gibberella fujikuorii, and prolylendopeptidase inhibition studies of transformed products. Turk J Chem 2010, 34:945-951.

7. Choudhary MI, Mohammad MY, Musharraf SG, Parvez M, Al-Aboudi A, Atta-ur-Rahman: New oxandrolone derivatives by biotransformation using Rhizopus stolonifer. Steroids 2009, 74:1040-1044.

8. Choudhary MI, Khan NT, Musharraf SG, Anjum S, Atta-ur-Rahman: Biotransformation of adrenosterone by filamentous fungus. Cunninghamella elegans. Steroids 2007, 72:923-929.

9. Hengge UR, Stocks K, Faulkner S, Wiehler H, Lorenz C, Jentzen W, Hengge D, Ringham G: Oxymetholone for the treatment of HIV-wasting: a double-blind, randomized, placebo-controlled phase III trial in eugonadal men and women. HIV Clin Trials 2003, 4:150-163.

10. Pavlatos AM, Fultz O, Monberg MJ, Vootkur A: Review of oxymetholone: a 17a-alkylated anabolic-androgenic steroid. Clin Ther 2001, 23:789-801.

11. Karrow NA, McCay JA, Brown R, Musgrove D, Munson AE, White KL Jr: Oxymetholone modulates cell-mediated immunity in male B6C3F1 mice. Drug Chem Toxicol 2000, 23:621-644.

12. Mukaida N, Morita M, Ishikawa Y, Rice N, Okamoto S, Kasahara T, Matsushima K: Novel mechanism of glucocorticoid-mediated gene repression. Nuclear factor-kappa B is target for glucocorticoid-mediated interleukin 8 gene repression. J Biol Chem 1994, 269:13289-13295.

13. Chuhjo T, Yachie A, Kanegane H, Kimura H, Shiobara S, Nakao S: EpsteinBarr virus (EBV)-associated post-transplantation lymphoproliferative disorder simultaneously affecting both $B$ and $T$ cells after allogeneic bone marrow transplantation. Am J Hematol 2003, 72:255-258.

14. Filippin LI, Vercelino R, Marroni NP, Xavier RM: Redox signalling and the inflammatory response in rheumatoid arthritis. Clin Exp Immunol 2008, 152:415-422.

15. Knox LH, Velarde E: Steroids. CCXIV.1 2a-Hydroxymethylandrostane derivatives. J Org Chem 1962, 27:3925-3929.

16. Bond AM, Dakternieks D, Deprez PP, Zuman P: Polarographic and spectroscopic examination of the reaction of the anabolic steroid oxymetholone with methanol and ethanol. J Org Chem 1988, 53:1991-1996

17. Siemens: SMART and SAINT. Madison: Siemens Analytical X-Ray Instruments Inc: 1996.

18. Altomare A, Cascarano G, Giacovazzo C, Guagliardi A: Completion and refinement of crystal structures with SIR92. J App/ Cryst 1993, 26:343-350

19. Sheldrick GM: SHELXTL-PC (Version 5.1). Madison: Siemens Analytical Instruments, Inc; 1997.

20. Jhnson CK: 'ORTEPII', Report ORNL-5138. Tennessee: Oak Ridge National Laboratory; 1976.

21. Böyum A: Isolation of mononuclear cells and granulocytes from human blood. Isolation of monuclear cells by one centrifugation and of granulocytes by combining centrifugation and sedimentation at $1 \mathrm{~g}$. Scand I Clin Lab Invest 1968, 97:77-89.

22. Nielsen M, Gerwien J, Geisler C, Röpke C, Svejgaard A, Odum N: MHC class II ligation induces CD58 (LFA-3)-mediated adhesion in human T cells. Exp Clin Immunogenet 1998, 15:61-68.

23. Helfand SL, Werkmeister J, Roder JC: Chemiluminescence response of human natural killer cells. I. The relationship between target cell binding, chemiluminescence, and cytolysis. J Exp Med 1982, 156:492-505.

24. Mosmann T: Rapid colorimetric assay for cellular growth and survival: application to proliferation and cytotoxicity assays. J Immunol Methods 1983, 65:55-63.

25. Choudhary MI, Ismail M, Shaari K, Abbaskhan A, Sattar SA, Lajis NH, Atta-urRahman: Cis-Clerodane-type furanoditerpenoids from Tinospora crispa. $J$ Nat Prod 2010, 73:541-547.

doi:10.1186/1752-153X-6-153

Cite this article as: Khan et al: Synthesis of some potent immunomodulatory and anti-inflammatory metabolites by fungal transformation of anabolic steroid oxymetholone. Chemistry Central Journal 2012 6:153 